\title{
Da pessoa abstrata do Estado ao governo dos homens: Estado e soberania na obra de Thomas Hobbes
}

\author{
Felipe Freller*
}

\begin{abstract}
Resumo: 0 artigo tem como objetivo discutir o enigma de como a teoria política hobbesiana consegue enunciar a soberania de um Estado pensado em termos totalmente impessoais e abstratos, como um órgão autônomo em relação às pessoas dos governantes e governados (aspecto do pensamento de Hobbes notado por Quentin Skinner), e ao mesmo tempo defender o poder absoluto de um ou de alguns homens sobre seus súditos (aspecto do pensamento de Hobbes que motivou a crítica de James Harrington, contemporâneo do filósofo inglês). Em uma primeira parte, o artigo procura entender as motivações políticas que levaram Hobbes a formular essa concepção impessoal e abstrata da soberania, situando-a no contexto dos embates teórico-políticos resultantes da guerra civil inglesa. Em uma segunda parte, procura-se mostrar por que um Estado concebido dessa maneira abstrata só pode agir por meio do poder absoluto de um ou alguns homens. Por fim, uma terceira parte se dedica a compreender, à luz do argumento das partes anteriores, a crítica de Harrington segundo a qual Hobbes defende um governo de homens e não de leis.
\end{abstract}

Palavras-chave: Hobbes, Estado, soberania, Harrington.

\section{Introdução}

Este artigo nasce da sensação de que a obra de Thomas Hobbes pode suscitar (e de fato suscitou) leituras focadas em aspectos muito diferentes, aparentemente até contraditórios, do pensamento desse autor, especialmente no que diz respeito a sua teoria da soberania. Nosso ponto de partida é o contraste nas ênfases empregadas nos comentários de dois importantes leitores de Hobbes: o comentarista contemporâneo Quentin Skinner e o republicano inglês James Harrington, talvez o crítico mais consistente de Hobbes na década de 1650.

Skinner enfatiza, em sua compreensão da teoria hobbesiana da soberania, o pertencimento dessa soberania ao Estado, pensado de forma inteiramente impessoal e abstrata, como uma esfera totalmente autônoma, independente tanto das pessoas dos governantes como das pessoas dos governados. Em sua visão,

\footnotetext{
${ }^{*}$ Graduando em Ciências Sociais - USP.
} 
Hobbes é o primeiro autor a pensar de modo autoconsciente o Estado (e não o príncipe ou o povo, por exemplo) como objeto por excelência da Ciência Política. É essa centralidade do Estado que faz da teoria hobbesiana um divisor de águas na história do discurso político:

It announces the end of an era in which the concept of public power had been analysed in more personal and charismatic terms. It points to a simpler and more abstract vision of sovereignty as the property of an impersonal agency, a vision that has remained with us ever since and has come to be embodied in the use of such terms as état, stato, Staat and state (SKINNER, 2002a, p. 368-369).

Todavia, não parece ter sido essa profunda inovação conceitual e linguística referente ao conceito de Estado que chamou a atenção e motivou os comentários dos contemporâneos de Hobbes, pelo menos não os de um de seus mais articulados antagonistas, James Harrington. Em sua obra The Commonwealth of Oceana and a System of Politics, escrita em 1656, com o propósito explícito de combater as teses do Leviatã, a soberania hobbesiana não é encarada, como foi por Skinner, pela ótica da impessoalidade e da abstração, mas, ao contrário, pela ótica da dominação pessoal, do império dos homens, de seus arbítrios e interesses pessoais. Com efeito, Harrington lê Hobbes como um defensor da prudência moderna, a qual define o governo como

[...] an art whereby some man, or some few men, subject a city or a nation, and rule it according unto his or their private interest, which, because the laws in such cases are made according to the interest of a man or of some families, may be said to be the empire of men and not of laws (HARRINGTON, 1992, p. 9).

Assim, a soberania hobbesiana não é encarada pelo republicano como a propriedade de um agente impessoal, mas, ao contrário, como a expressão máxima do governo dos homens (como oposto ao governo das leis, aquele defendido pela prudência antiga).

Um aparente enigma então se constitui no interior do pensamento de Hobbes. Levar em conta apenas que o filósofo atribui a sede da soberania a um Estado pensado de forma impessoal e abstrata (como aponta Skinner) pode levar a interpretações segundo as quais o Estado soberano, enquanto aparato político independente das pessoas dos governantes, limita o poder desses governantes, impedindo a existência de uma dominação pessoal. Essa interpretação (para nós 
equivocada) entra em franca contradição com a leitura que Harrington faz de Hobbes.

A nosso ver, esse enigma não pode ser resolvido escolhendo-se entre a leitura de Skinner ou a de Harrington, pois ambas nos parecem apontar para aspectos presentes de fato no pensamento de Hobbes. Por um lado, seu propósito de construir uma soberania impessoal e abstrata é declarado já na Epístola Dedicatória do Leviatã, quando o autor afirma: "não é dos homens no poder que falo, e sim (em abstrato) da sede do poder" (HoBBES, 2003, p. 5).

Por outro lado, a consequência de sua teoria da soberania é de fato o poder absoluto de um ou alguns homens (ou ainda de uma maioria de homens em uma assembleia democrática) sobre outros, parecendo-nos correta a compreensão de Harrington de que se trata de um governo de arbítrios pessoais. Skinner não está mais correto do que Harrington (ou vice-versa), os dois parecem apenas enfatizar aspectos diferentes, mas igualmente presentes e importantes no pensamento de Hobbes.

O objetivo deste artigo é resolver o aparente enigma apontado anteriormente, explorando como esses dois aspectos aparentemente contraditórios da teoria hobbesiana da soberania (sua abstração e impessoalidade e seu caráter absolutista que se traduz no que Harrington chama de "governo dos homens") se articulam no interior da obra de maior repercussão do filósofo inglês: Leviatã. A literatura recente sobre Hobbes parece nos oferecer excelentes contribuições para explorar cada um desses aspectos da teoria hobbesiana separadamente $^{1}$, mas até agora não chegamos a ler nenhum texto que formule o já mencionado enigma, o qual se forma com base nos dois aspectos aparentemente contraditórios da teoria, um em relação ao outro.

Skinner, em seu texto "Hobbes and the purely artificial person of the state", formula um enigma que se aproxima do formulado por nós, ao perguntar como o

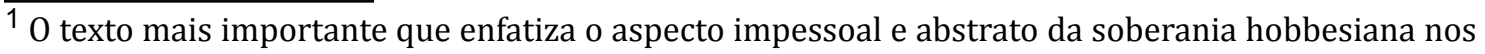
parece ser "From the state of princes to the person of the state", de Quentin Skinner. O outro aspecto com que estamos trabalhando pode ser apreendido com clareza de textos como "Leviatã e Oceana", de Eunice Ostrensky, o qual trabalha o Leviatã como proposta constitucional endereçada à resolução da crise inglesa do século XVII e confronta essa proposta constitucional com a de Harrington. A proposta constitucional hobbesiana, vista aos olhos de Harrington, aparece como a tentativa de "converter a Inglaterra numa monarquia absoluta de tipo turco" (OSTRENSKY, 2009, p. 43).
} 
Estado, sendo uma abstração, é capaz de ação. A resposta dada por Skinner nesse texto será incorporada ao nosso argumento, mas ela não nos parece responder automaticamente como se dá a passagem para o "governo dos homens" apontado (e criticado) por Harrington.

A relação entre os dois aspectos aparentemente contraditórios da teoria de Hobbes será estudada neste artigo por meio de duas perguntas. A primeira é por que o autor decidiu defender o poder absoluto de um ou alguns homens sobre outros com base em uma teoria da soberania pertencente a um Estado concebido de modo impessoal e abstrato, em vez de simplesmente reiterar as teorias patriarcalistas e do direito divino dos reis apresentadas pelos realistas. A segunda é de que modo essa concepção do Estado impessoal e abstrato como sede da soberania não acarreta uma diminuição do poder pessoal dos governantes, mas, pelo contrário, garante-lhes o poder absoluto sobre seus súditos.

Inspirando-se na metodologia contextualista da chamada Escola de Cambridge de história do pensamento político, o artigo procurará responder à primeira questão remetendo a obra de Hobbes ao embate nada pacífico de forças políticas que ocorria em sua época, um embate no qual as ideias e teorias não deixaram de ser armas importantes. Se a abordagem contextualista talvez não esgote a questão de por que o autor formulou sua concepção do Estado impessoal e abstrato (é sempre possível remeter as formulações político-filosóficas às convicções pessoais dos autores, à necessidade de dar coerência interna à obra etc.), é certo que ela possibilita uma relação não anacrônica com a teoria, permitindo compreender o significado que ela teve em sua época e as intenções políticas que orientaram sua formulação ${ }^{2}$.

Desse modo, procuraremos ver a formulação hobbesiana da soberania do Estado impessoal e abstrato como uma arma contra "aqueles que, se batem de um lado, por excessiva liberdade, e, de outro, por excessiva autoridade" (HoBBES, 2003, p. 5), segundo as palavras do próprio autor na Epístola Dedicatória do Leviatã.

Em 1651, quando Leviatã foi publicado, aqueles que se batiam "por excessiva autoridade", os realistas, estavam entre os que não aceitavam o novo

\footnotetext{
${ }^{2}$ Nas palavras de Skinner endossadas por Pocock, a abordagem contextualista permite "saber o que um autor 'estava fazendo' quando publicou um texto determinado" (Рососк, 2003, p. 75).
} 
regime político (oficialmente republicano), inaugurado após a execução de Carlos I, o que os colocavam na condição de subversores da autoridade constituída e, portanto, de inimigos de Hobbes. Nesse contexto, a concepção pessoal e mesmo corpórea da soberania (no sentido de pensada como pertencente naturalmente ao corpo do monarca) invocada pelos realistas em suas teorias patriarcalistas e do direito divino dos reis não servia para legitimar o poder adquirido pelas armas do Conselho de Estado $^{3}$, mas, ao contrário, para contestá-lo.

Assim, a concepção puramente abstrata e impessoal do Estado formulada por Hobbes podia servir para legitimar o poder do Conselho de Estado contra os realistas, os quais não se preocupavam com a sede abstrata do poder, mas com os homens que devem ocupar o poder (vendo legitimidade somente na autoridade de homens cuja linhagem, em sua consideração, provinha de Deus).

Não obstante, a formulação de um teoria absolutista com base em uma concepção puramente abstrata e impessoal do Estado parecia servir também, e principalmente, para enfrentar aqueles que se batiam "por excessiva liberdade" em seu próprio terreno (portanto, de modo mais eficaz que as teorias patriarcalistas e do direito divino dos reis). De fato, algumas das teorias subversivas formuladas durante a guerra civil inglesa se inspiravam em teorias republicanas e monarcômacas, as quais, segundo Skinner, constituíram um passo importante, embora não definitivo, na formulação de uma concepção impessoal do Estado.

O passo definitivo de Hobbes rumo a uma concepção puramente abstrata do Estado pode ser pensado como mais uma de suas estratégias no sentido de reverter o sentido de linguagens políticas usadas em discursos subversivos, de modo que se construísse uma teoria infalível da autoridade absoluta com base nos despojos das teorias adversárias. A primeira parte do artigo se dedicará a entender de que modo a teoria hobbesiana da soberania impessoal e abstrata pode ser entendida como uma resposta a essas teorias subversivas.

Contudo, entender as intenções políticas que levaram Hobbes a formular sua concepção impessoal e abstrata do Estado não é suficiente para responder à segunda pergunta do artigo, referente a como esse Estado impessoal e abstrato

\footnotetext{
3 Órgão executivo do regime republicano inaugurado na Inglaterra em 1649, após a execução do Rei Carlos I.
} 
garante o poder absoluto e pessoal dos governantes. Essa segunda pergunta será respondida na segunda parte do artigo, na qual abandonaremos momentaneamente a abordagem contextualista e analisaremos, no plano da argumentação abstrata de Hobbes, como o Estado abstrato é capaz de ação e por que essa ação só é possível pelo poder absoluto e pessoal de um ou alguns homens. $\mathrm{Na}$ terceira parte do artigo, voltaremos a uma abordagem contextualista ao dimensionar as consequências políticas da teoria hobbesiana da soberania à luz de sua recepção por Harrington.

\section{Primeira parte}

0 período da guerra civil inglesa da década de 1640 foi marcado por um acirrado debate teórico em torno da questão de qual é a sede legítima da soberania. As respostas a essa questão, longe de serem especulações filosóficas distantes da realidade, delimitavam quais ações eram possíveis em um cenário político sem precedentes, de guerra entre o rei e o Parlamento ${ }^{4}$. Nesse período, a maior parte das teorias que dissociavam a sede da soberania da pessoa do rei, associando-a a algo como o Estado, ou, na ausência dessa palavra, ao menos pensando-a em termos impessoais, era considerada subversiva e antirrealista.

Alguns defensores do Parlamento - notoriamente Henry Parker, que escreveu Observations upon his Majesties late answer em 1642 - retomaram alguns princípios das teorias monarcômacas formuladas no contexto das guerras religiosas do final do século XVI. Segundo essas teorias, o povo existe como unidade antes de haver poder político, e este só pode ser criado por consentimento do povo. Uma vez instituído o poder político, é importante distinguir entre o cargo jurídico, a sede da soberania, e a pessoa do governante que concordou em ocupar este cargo para o bem do povo que o instituiu. Caso o rei não cumpra o pacto e governe apenas para seu próprio bem, perde o direito ao cargo que pertence ao povo, e este tem o direito de destituí-lo.

Segundo a apropriação dessa linguagem monarcômaca por parte de Parker, "violadas as condições do pacto, o poder supremo não retorna ao povo como

\footnotetext{
${ }^{4}$ Como afirma Skinner, "o que é possível fazer em política é geralmente limitado pelo que é possível legitimar" (SKINNER, 1999, p. 86).
} 
multidão dispersa, mas somente ao povo como sociedade política organizada" (OSTREnSKY, 2010, p. 154), ou seja, ao Parlamento, o qual, segundo o parlamentarista, representava perfeitamente o povo inglês. Assim, para Parker e outros parlamentaristas, havia uma correspondência entre povo, Parlamento e Estado, e esses três elementos correspondentes eram a sede legítima da soberania, além de responsáveis pela resistência à tirania do rei.

Depois que o exército parlamentarista venceu o realista, em 1646, e o próprio Parlamento começou a praticar atos considerados por muitos como tirânicos, os (pejorativamente) chamados levellers passaram a criticar essa versão parlamentarista da tese da soberania popular, questionando justamente a alegada capacidade do Parlamento de representar perfeitamente o povo inglês. Para eles, a soberania pertence diretamente ao povo, ou seja, a cada um dos homens livres e proprietários de si que se submetem às leis do reino.

Dessa forma, o papel do Parlamento não é substituir o povo, mas antes espelhá-lo da maneira mais fiel possível. As soluções para esse problema, apresentadas no Acordo do povo, de 1647, consistem em adotar o sufrágio universal, a representação proporcional e o mandato parlamentar limitado a dois anos. Além disso, para garantir que a soberania pertença aos representados e não aos representantes, aqueles devem guardar para si certos poderes que não são confiados a estes. Os assuntos de religião e a decisão de servir ou não na guerra são exclusivos dos representados.

0 último discurso subversivo baseado em uma concepção impessoal da soberania que analisaremos é o panfleto "A tenência de reis e magistrados", de John Milton, escrito em 1649 para justificar o golpe do Exército de Novo Tipo ${ }^{5}$ sobre o Parlamento, o julgamento e a execução de Carlos I. Nesse panfleto, Milton mescla argumentos monarcômacos e republicanos. A linguagem monarcômaca se faz notar pela consideração de que é o povo que institui os reis e magistrados, confiando a eles o poder de punir a violência decorrente da transgressão de Adão, porém sem

\footnotetext{
${ }^{5}$ Exército parlamentarista comandado e modernizado por Oliver Cromwell, no qual era admitida a livre expressão de opiniões religiosas e indivíduos de baixa extração podiam alcançar posições destacadas. Em 6 de dezembro de 1648, esse exército deu um golpe sobre o Parlamento, excluindo membros que negociavam a restauração de Carlos I e assim abrindo caminho para a execução do monarca.
} 
alienar seu direito natural de ser juiz da lei de natureza e portanto de depor, julgar e punir os governantes que, em sua consideração, se comportarem como tiranos.

A principal divergência de Milton com a apropriação parlamentarista da linguagem monarcômaca é que, para ele, os parlamentares, ou magistrados inferiores, encontram-se na mesma posição do rei: de representantes obrigados a prestar contas ao povo, cabendo a este, diretamente - ou melhor, por meio do Exército de Novo Tipo -, a responsabilidade pela deposição e punição dos tiranos. 0 autor articula essa linguagem monarcômaca dentro de um registro republicano, que se preocupa com a manutenção da liberdade do Estado, entendida como autogoverno, submissão somente às leis feitas pelo próprio povo, jamais a uma vontade arbitrária e externa à comunidade ${ }^{6}$. 0 direito de revolução é formulado como uma garantia dessa liberdade do Estado, entendido quase como sinônimo de povo e pensado como a sede legítima da soberania.

Embora tenham sido formulados por grupos políticos adversários, esses três discursos têm um ponto em comum: retiram a soberania da pessoa do rei, obrigando-o a se submeter, como qualquer outro cidadão, a leis impessoais; a soberania é atribuída ao povo, ou, quando é usada a palavra "Estado", este é pensado praticamente como um sinônimo de povo. Pode-se atribuir a esses discursos a noção ainda não puramente abstrata do Estado que Skinner atribui às tradições republicana e monarcômaca (as quais, como tentamos mostrar, estão entre as camadas linguísticas ${ }^{7}$ mobilizadas por alguns desses autores):

\begin{abstract}
Although they separate sovereignty from sovereigns, however, the monarchomachs make no comparable distinction between the powers of sovereignty and the powers of the people. Like the classical republicans, they embrace only one half of the doubly abstract notion of state authority. While they stress that sovereignty is the property of a legal person, the person whom they treat as the bearer of sovereignty is always the persona constituted by the corporate body of the people, never the impersonal body of the civitas or respublica itself (SKINNER, 2002a, p. 394).
\end{abstract}

\footnotetext{
6 “Corns, 1995, p. 26, diz de Milton, em Tenure, que ele parece 'mais um regicida que um republicano'. Não discordo, mas as referências de Milton a Estados livres e servidão pessoal mostram-no bem mais disposto do que os autores 'monarcômacos' da década de 1640 (tais como Henry Parker) a modular num registro republicano" (SKINNER, 1999, p. 66, nota 40).

7 Sobre o conceito de linguagem política e o trabalho do historiador do discurso político como uma arqueologia das camadas linguísitcas articuladas nos textos do passado, ver: Pocock (2003, cap. 2).
} 
Podemos ainda encontrar nesses discursos o pressuposto de que o povo soberano é naturalmente capaz de ação. Para Parker, o povo é capaz de resistir à tirania do rei por meio do Parlamento. Para os levellers, o povo é capaz de celebrar um acordo que defina o poder e o mandato dos representantes e os direitos inalienáveis dos representados. E, para Milton, o povo é capaz de instituir e, por meio do Exército, depor, julgar e punir os reis e magistrados.

Veremos agora como Hobbes refuta essas teorias da soberania popular sem retornar à concepção personalista e corpórea que os realistas tinham da soberania (o que seria impossível para um filósofo que concebia os homens como naturalmente iguais), mas, ao contrário, elaborando uma teoria da soberania ainda mais impessoal e abstrata do que aquelas que a atribuíam ao povo.

Um dos principais argumentos do filósofo inglês para desmontar as teses da soberania popular é o ataque ao pressuposto de que existe na natureza um povo unido e capaz de ação. Esse ataque se dá por meio da refutação da tese da sociabilidade natural, um dos objetivos centrais da parte 1 do Leviatã. Rompendose com esse pressuposto, torna-se um absurdo afirmar que o poder político deriva do povo e que este permanece como portador da soberania. Antes de haver poder político, sequer pode haver povo, mas apenas uma multidão de indivíduos dispersos, na qual as ações de cada um são determinadas por seu julgamento e apetites individuais.

Essas ações individuais não se guiam pelas leis de natureza (as quais, no estado de natureza, só obrigam in foro interno) ou por qualquer outra norma que tenda à paz e à sociabilidade, mas apenas pelo direito de natureza, ou seja, pela liberdade de usar todos os meios que cada um considere adequados para preservar a própria vida em um estado de guerra de todos contra todos. Tampouco existe um bem ou interesse comum que sirva de horizonte às ações individuais e possa unificá-las: bem e mal são apenas os nomes dos objetos dos apetites e aversões individuais, não se podendo estabelecer em torno disso uma regra baseada na natureza dos próprios objetos, e que portanto seja de aceitação universal entre os membros da multidão.

Assim, Hobbes, divergindo dos teóricos da soberania popular, não vê a instituição do poder político como uma ação do povo visando a fazer valer seus 
interesses comuns (não existe na natureza povo capaz de ação nem de ter interesses comuns), mas como um pacto entre cada membro da multidão e todos os outros (e não entre o povo e seus futuros governantes), visando justamente a transformar a multidão dispersa em um ser unificado capaz de ação (mais especificamente, capaz de garantir aos indivíduos segurança e proteção, o interesse que eles buscam ao instituir uma República). 0 autor não chama esse ser unificado de povo ${ }^{8}$, mas de República ou Estado, ou, em latim, Civitas, e afirma ser nesse grande Leviatã que reside a soberania.

Podemos supor que Hobbes evitou o termo "povo" por este ter sido usado pelos teóricos da soberania popular para designar um ser natural - o conjunto dos homens livres de um país, os quais teriam naturalmente interesses comuns e unidade de ação -, ao passo que o filósofo inglês recusava a existência desse ser natural e só concebia a unidade numa multidão como produto de um artifício. Esse artifício é a representação, por meio da qual todos os membros da multidão consentem em ser autores de todos os atos praticados pela pessoa do Estado, portador de suas pessoas:

Uma multidão de homens se torna uma pessoa quando é representada por um só homem ou pessoa, de maneira que tal seja feito com o consentimento de cada um dos que constituem essa multidão. Porque é a unidade do representante, e não a unidade do representado, que faz a pessoa ser una. E é o representante o portador da pessoa, e só de uma pessoa. E não é possível entender de nenhuma outra maneira a unidade numa multidão (HoBBES, 2003, p. 141; grifos do autor).

Portanto, se os teóricos da soberania popular tornaram a soberania impessoal ao afastá-la da pessoa do rei, Hobbes a tornou inteiramente abstrata ao afastá-la de qualquer ser existente na natureza, sejam os governantes ou o conjunto de membros da comunidade 9 . 0 órgão que porta a soberania, a República ou Estado ${ }^{10}$, não passa de uma abstração, de um nome para designar um fenômeno

\footnotetext{
${ }^{8}$ Embora em algumas passagens se refira ao soberano como o portador da pessoa do povo. Ver: Hobbes (2003, p. 160).

9 "More clearly than any previous writer on public power, Hobbes enunciates the doctrine that the legal person lying at the heart of politics is neither the persona of the people nor the official person of sovereign, but rather the artificial person of the state" (SKINNER, 2002a, p. 404).

${ }^{10}$ Cuja definição é "uma pessoa de cujos atos uma grande multidão, mediante pactos recíprocos uns com os outros, foi instituída por todos como autora, de modo que ela pode usar a força e os recursos de todos, da maneira que considerar conveniente, para assegurar a paz e a defesa comuns" (HoBBES, 2003, p. 148).
} 
impossível de se verificar na natureza e na experiência comum: uma multidão unificada.

\section{Segunda parte}

Trata-se agora de entender como o Estado - essa mera palavra, essa mera abstração - é capaz de exercer algum poder. Respondida essa pergunta, pretendemos ver por que esse poder só pode existir se for absoluto e, assim, solucionar o enigma que move este trabalho: como Hobbes passa de uma concepção inteiramente impessoal e abstrata da soberania ao poder absoluto de um ou alguns homens?

A primeira pergunta é o enigma que Skinner se propõe a resolver em seu texto "Hobbes and the purely artificial person of the state":

How can the state, an apparent abstraction, nevertheless be the name of the person who makes laws, punishes criminals, declares war and peace and performs all the other actions necessary for maintaining - in Hobbes's fine phrase - the safety of the people and their other contentments of life? (SKINNER, 2002b, p. 177-178).

Reproduziremos brevemente a resposta que o intérprete dá no texto referido, pois a consideramos um passo importante para responder nossa própria pergunta. Interpretando a teoria hobbesiana da representação, Skinner propõe o termo "pessoas puramente artificiais" (purely artificial persons) para designar uma categoria de pessoa que Hobbes não nomeou, mas que estava no centro de suas preocupações teóricas:

These are persons capable of being represented, but incapable of acting as authors in the distinctive manner of natural persons, and hence of authorising their own representatives. It follows that, while it is possible for such artificial persons to speak and act, it is possible for them to do so only if their words and actions can validly be attributed to them on the basis of their performance by some other person or collectivity licensed to act in their name (idem, p. 192; grifos do autor).

As palavras e ações de um agente podem ser atribuídas a uma pessoa puramente artificial por ficção, como quando as palavras e ações de um ator em uma encenação teatral são ficticiamente atribuídas à personagem que o ator está representando (na Inglaterra, do século XVII, até mesmo essa representação por ficção só era permitida se o ator tivesse uma autorização formal para isso). 
No entanto, existem pessoas puramente artificiais que podem ter ações verdadeiramente (e não meramente por ficção) atribuídas a elas. É o caso de objetos inanimados, como uma igreja, um hospital ou uma ponte, aos quais pode-se verdadeiramente atribuir as ações de um reitor, diretor ou supervisor, desde que estes tenham recebido autoridade dos donos ou governadores dessas coisas; de seres irracionais (crianças, débeis, loucos), os quais não podem autorizar sua representação por guardiões ou curadores, mas esta pode ocorrer por meio da autorização daquele que tem o direito de os governar; e mesmo de seres imaginários, como os deuses pagãos, os quais, mediante autorização do Estado, podiam ser personificados por funcionários e assim receber posses, bens e direitos.

O Estado pertence a essa última espécie de pessoas puramente artificiais, e sua condição é análoga à dos deuses pagãos. Como vimos, o Estado, como multidão unificada, é uma mera abstração, tão inexistente na realidade concreta quanto os deuses pagãos. Contudo, é possível que um homem ou assembleia de homens receba autoridade para atuar em seu nome, de modo que suas palavras e ações sejam verdadeiramente atribuídas à pessoa abstrata do Estado. Essa autoridade deve ser conferida por cada um dos membros da multidão.

Assim, Skinner mostra como uma palavra abstrata é capaz de agir e exercer o poder soberano: através de sua representação por pessoas naturais e concretas. A representação é uma condição necessária não só para a criação do Estado, mas também para que este seja capaz de ação ${ }^{11}$.

$\overline{11}$ Há, portanto, uma dupla representação: o Estado representa cada um dos membros da multidão,
ao passo que o soberano representa o Estado. Alguns comentadores falam da representação em
Hobbes como conectando as ações do soberano com cada um dos membros da multidão que
autorizou essas ações. De fato há essa conexão, mas esses comentadores não parecem perceber que
essa conexão é mediada por duas representações: a primeira se estabelece quando, para se produzir
a unidade em uma multidão, cada indivíduo se faz autor dos atos de uma pessoa abstrata, o Estado
ou República; a segunda representação se estabelece na medida em que, para que essa pessoa
abstrata e sem existência concreta seja capaz de agir, é necessário que alguma pessoa concreta (um
homem ou uma assembleia) seja portador dessa pessoa artificial, mediante a autorização de cada
um dos membros da multidão. Essa pessoa concreta é o soberano, definido como "portador dessa
pessoa [da República]" (HoBbes, 2003, p. 148). Assim, é apenas porque o soberano representa o
Estado, o qual representa cada um dos membros da multidão, que o soberano representa cada um
dos membros da multidão. Os comentadores que não percebem essa dupla representação parecem
não percebê-la por não perceberem que a sede da soberania é um Estado abstrato (como enfatizou
Skinner) e não a pessoa concreta do soberano. Hanna Fenichel Pitkin, por exemplo, vê a teoria
hobbesiana da representação como uma solução formalista para o seguinte problema: "the problem
of creating a lasting union out of a multitude of separate men with separate conflicting wills"
(PITKIN, 1967, p. 35). Todavia, esse é o problema que leva à primeira representação. O problema que
leva à segunda representação diz respeito à necessidade de conferir capacidade de ação a uma 
Resta entender por que o Estado só pode exercer algum poder se esse poder for absoluto. Em primeiro lugar, esse poder só pode existir se for indivisível. Se os homens criam o Estado justamente para transformar uma multidão dispersa em uma unidade, dividir o poder soberano é o mesmo que romper essa unidade, criando diferentes poderes que lutarão uns contra os outros, levando a República à guerra civil e à dissolução ${ }^{12}$. Isso significa que, se o Estado, pelas razões apontadas por Skinner, deve ser representado, seu representante deve ser uma única pessoa (um homem ou uma assembleia capaz de, por votação, chegar a uma única vontade), a qual não compartilhará a soberania com mais ninguém, sob o risco de o Estado perder seus poderes mais fundamentais.

Em segundo lugar, essa pessoa deve estar acima das leis, uma vez que estas só são obrigatórias quando há um poder coercitivo capaz de impô-las pela força, de modo que leis acima do soberano implicariam um poder coercitivo acima do soberano, o que criaria outra soberania e seria incompatível com a indivisibilidade do poder soberano ${ }^{13}$. Assim, Hobbes entende por poder absoluto o poder indivisível e acima das leis (portanto ilimitado) de uma única pessoa, e demonstra ser essa a única forma pela qual um Estado, devido a sua condição abstrata, pode agir e exercer poder.

\section{Terceira parte}

Vimos, na primeira parte do artigo, as intenções políticas que estiveram por trás da formulação hobbesiana da soberania de um Estado impessoal e abstrato. Na segunda parte, examinamos como essa formulação leva ao poder absoluto de um homem ou assembleia de homens. Resta discutir, diante dessa compreensão da teoria hobbesiana da soberania, o sentido da crítica de Harrington. Em que sentido o poder absoluto (no sentido especificado anteriormente) de um homem ou assembleia pode ser qualificado como um governo dos homens e não das leis?

\footnotetext{
pessoa abstrata, problema exposto por Skinner (2002b), mas não abordado por Pitkin.

12 "Pois em que consiste dividir o poder de uma república senão em dissolvê-lo? - uma vez que os poderes divididos se destroem mutuamente uns aos outros" (HoBBEs, 2003, p. 276).

13 "Este erro, porque coloca as leis acima do soberano, coloca também um juiz acima dele, com poder para castigá-lo, o que é fazer um novo soberano, e também pela mesma razão um terceiro para castigar o segundo, e assim sucessivamente, para confusão e dissolução da república" (HOBBES, 2003, p. 275).
} 
Cabe observar que a crítica de Harrington não é simplesmente à existência de um poder absoluto. Em uma passagem de seu texto de 1659, "A arte de legislar", o republicano também defende que o poder soberano deve ser absoluto. 0 autor o faz no contexto de uma crítica a uma cláusula dos levellers segundo a qual o povo poderia opor resistência armada ao poder soberano. Contra essa cláusula, Harrington afirma:

Isso constitui uma contradição manifesta e o próximo passo é inequivocamente a anarquia. Quando o poder soberano não é pleno e absoluto como na própria monarquia, não existe governo algum. A causa de uma república não é a limitação do poder soberano, mas uma tal libração ou gravidade das ordens, que nela não haja um número de homens que, tendo o interesse, tenha o poder, nem um número de homens que, tendo o poder, tenha o interesse de invadir ou perturbar o governo (HARRINGTON, 2010, p. 20; grifos do autor).

É interessante notar que, nesse aspecto, Harrington demonstra uma irritação semelhante à de Hobbes com a recusa dos levellers (e, poder-se-ia dizer, também de Milton) de delimitar de uma vez por todas quem detém a soberania e de obedecer esse detentor, preferindo confiar a liberdade do país na possibilidade de agitações e guerras civis. Todavia, Harrington tem uma concepção diferente da de Hobbes sobre o que é uma soberania absoluta.

Segundo Harrington, a soberania absoluta não precisa ser indivisível e acima das leis, mas pode, segundo a fórmula republicana clássica, basear-se em um governo misto em que o poder da República não se resuma a um corpo único (e portanto a um interesse único; seu objeto é o interesse comum). Mediante uma libração ou gravidade adequada das ordens (sendo proposta por Harrington a divisão dos poderes entre o Senado que propõe, a assembleia popular que decide e o magistrado que executa), pode-se garantir ao mesmo tempo um poder soberano pleno e absoluto e o governo da lei e do interesse comum.

Assim, a crítica de Harrington a Hobbes não é à mera existência de um poder absoluto, mas à defesa de um poder absoluto de homens (e não de leis), o que se traduz em um governo voluntarista, dirigido pelo arbítrio desses homens e pela busca de seus interesses privados. Ora, Hobbes provavelmente não discordaria dessa interpretação de sua teoria. Não se pode acusá-lo de ter sido ingênuo quanto às implicações de atribuir a soberania a uma entidade abstrata que só pode agir 
mediante sua representação por uma pessoa natural única com poder indivisível e acima das leis. Ele estava ciente que a pessoa natural que representa o Estado provavelmente usaria seu poder para perseguir interesses privados:

Em primeiro lugar, seja quem for o portador da pessoa do povo, ou membro da assembleia que dela é portadora, é também portador da sua própria pessoa natural. Embora tenha o cuidado, na sua pessoa política, de promover o interesse comum, terá mais ainda, ou não terá menos cuidado de promover o seu próprio bem pessoal, assim como o da sua família, seus parentes e amigos. E, na maior parte dos casos, se porventura houver conflito entre o interesse público e o interesse pessoal, preferirá o interesse pessoal, pois em geral as paixões humanas são mais fortes do que a razão (HoBBES, 2003, p. 160).

O que se passa é que, de acordo com Hobbes, esse caráter voluntarista do poder soberano não é específico de formas pervertidas de governo mas um atributo da própria soberania, em decorrência de sua necessidade de ser exercida por uma pessoa natural única com poder indivisível e acima das leis. Desse modo, o filósofo rejeita enfaticamente a distinção aristotélica entre formas puras de governo (voltadas à lei e ao bem comum) e formas pervertidas (voltadas ao arbítrio e ao bem privado), afirmando que essa distinção não se refere às próprias formas de governo, mas ao fato de o governo ser amado ou odiado. Todo governo tenderá a promover o bem pessoal dos governantes.

O autor ainda afirma, para choque dos republicanos, democratas e aristocratas, que esse caráter voluntarista do poder soberano não é exclusivo da monarquia, sendo a dissociação entre interesse público e privado maior nos regimes em que o Estado é representado por uma assembleia ${ }^{14}$. Hobbes admite que essa sujeição às paixões irregulares dos representantes do Estado apresenta certas incomodidades, mas estas não chegam perto das calamidades resultantes da guerra civil e da dissolução da unidade do poder soberano. Ademais, a política não é concebida como a instância em que se busca a felicidade pública, mas como o artifício que permite aos homens buscar sua felicidade privada com paz e tranquilidade.

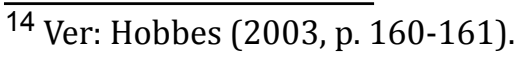


A crítica de Harrington a Hobbes só faz sentido porque o primeiro, ao contrário do segundo, acreditava ser possível um governo de leis e não de homens, o que dependia do fato de as leis serem feitas por um homem ou por vários:

Todas as leis são feitas por homens, mas, quando a lei é feita por um homem, ela pode ser desfeita por um homem, de modo que o homem não é governado pela lei, mas a lei pelo homem. Isso equivale ao governo do homem, não ao da lei. Por outro lado, se a lei foi feita por muitos, nenhum homem é governado por outro homem, mas unicamente por aquilo que constitui interesse comum, razão pela qual isso equivale a um governo das leis, não dos homens (HARRINGTON, 2010, p. 2).

Nesse sentido, a crítica de Harrington a Hobbes só é plausível porque os dois autores se situam em planos analíticos muito distintos. Enquanto Hobbes procura legitimar o poder absoluto dos soberanos com base na representação de uma entidade abstrata, a qual representa cada um dos súditos - colocando em segundo plano quem deve ser a pessoa concreta a representar o Estado (um monarca, uma assembleia aristocrática ou uma assembleia popular) e assim a questão das formas de governo -, Harrington, seguindo os republicanos clássicos, volta a conferir importância central às formas de governo, definindo a monarquia como um governo de homens e a soberania popular como um governo de leis.

$\mathrm{Na}$ verdade, Harrington se situa em outro plano analítico em relação a Hobbes não só ao retomar a questão das formas de governo, mas também - e principalmente - ao encarar as formas de governo como superestruturas que devem se adequar à fundação material do país, associada à distribuição da propriedade fundiária. Aos olhos do republicano, sustentar a defesa de uma monarquia absoluta com base na representação da palavra abstrata "Estado" é abstrair de modo temeroso as condições materiais da sociedade e abrir caminho para mais uma forma de governo que não se sustentará na Inglaterra, por causa da distribuição da propriedade fundiária nas mãos do povo.

\section{Conclusão}

A Introdução do artigo aponta para um enigma no interior do pensamento de Hobbes: a atribuição da soberania a um Estado pensado de modo impessoal e abstrato unida à defesa do governo dos homens, de seus arbítrios, paixões e 
interesses pessoais. Procuramos resolver o enigma mostrando que o Estado impessoal formulado por Hobbes não é o concebido pelos teóricos da soberania popular (como os parlamentaristas, os levellers e Milton, com suas reatualizações das linguagens monarcômaca e republicana), mas, ao contrário, é uma resposta a esses teóricos - uma resposta que faz o Estado ficar ainda mais abstrato, ao dissociá-lo de qualquer ser existente na natureza, inclusive de um suposto povo naturalmente capaz de ação.

Sendo uma total abstração, o Estado concebido dessa forma só pode agir por meio de sua representação por uma pessoa natural única com poder indivisível e acima das leis. A análise da crítica de Harrington permite ver que, não apenas a soberania assim concebida é absoluta, mas, o que é ainda mais chocante, resulta no governo absoluto de homens e não de leis. Desse modo, buscamos fazer um caminho que passasse do aspecto do pensamento hobbesiano enfatizado por Skinner ao aspecto desse pensamento enfatizado por Harrington, sem negar a existência de nenhum dos dois aspectos (buscando antes ver sua articulação).

Por fim, uma possível compreensão da articulação dos dois aspectos aparentemente contraditórios é encará-los como uma construção teórica, por um lado, e uma proposta prático-política, por outro. A proposta prático-política contida no Leviatã ${ }^{15}$ é o poder absoluto e ilimitado de um homem sobre seus súditos, o que faz Hobbes se aproximar dos realistas (com a exceção do ponto importante de que o filósofo, diferentemente dos demais defensores do absolutismo, defendia que os súditos deviam ter ao menos um direito inalienável, o de defender o próprio corpo dos ataques do soberano, uma vez que um pacto que visa à preservação da vida não pode impedir ninguém de evitar a própria morte). Entretanto, essa proposta prático-política (que chamou a atenção e motivou a crítica de Harrington) é sustentada por uma construção teórica totalmente inovadora (a qual chamou a atenção de Skinner), a do Estado impessoal e abstrato. No plano da construção teórica, Hobbes se distancia radicalmente dos realistas.

$\overline{15}$ Para uma compreensão do Leviatã como proposta constitucional, ver: Ostrensky (2009). 


\section{Referências}

Harrington, J. (1992). The Commonwealth of Oceana and a System of Politics. Cambridge, Cambridge University Press. . (2010). A arte de legislar. Trad. de E. Ostrensky. São Paulo, Datilo.

HobBes, T. (2003). Leviatã. Trad. de J. P. Monteiro e M. B. N. Silva. São Paulo, Martins Fontes.

Members of the New Model Army and civilian levellers (1998). "Extracts from the Debates of Putney". In: SHARP, A. (ed.). The English Levellers. Cambridge, Cambridge University Press.

Milton, J. (2005). "A tenência de reis e magistrados". In: Dzelzainis, M. (org.). Escritos Políticos. Trad. de E. Ostrensky. São Paulo, Martins Fontes.

Ostrensky, E. (2009). “Leviatã e Oceana”. In: Villanova, M. G.; BARRos, D. F. (orgs.). Hobbes: Natureza, história e política. São Paulo/Córdoba, Discurso Editorial/Editorial Brujas, vol. 1, p. 33-44.

(2010). "Soberania e representação: Hobbes, parlamentaristas e levellers". Lua Nova, São Paulo, n. 80, p. 151-179.

PitKin, H. F. (1967). The concept of representation. Berkeley, University of California Press.

Pocock, J. (2003). Linguagens do ideário político. Trad. de F. Fernandez. São Paulo, EDUSP.

Skinner, Q. (1999). Liberdade antes do Liberalismo. Trad. de R. Filker. São Paulo, UNESP.

. (2002a). "From the state of princes to the person of the state". In:

Visions of Politics - vol. II: Renaissance Virtues. Cambridge, Cambridge University Press.

(2002b). "Hobbes and the purely artificial person of the state". In:

Visions of Politics - vol. III: Hobbes and Civil Science. Cambridge, Cambridge University Press.

Recebido em fevereiro/2011

Aprovado em julho/2011 